\title{
Sponge City Program (SCP) and Urban Flood Management (UFM) - The Case of Guiyang, SW China
}

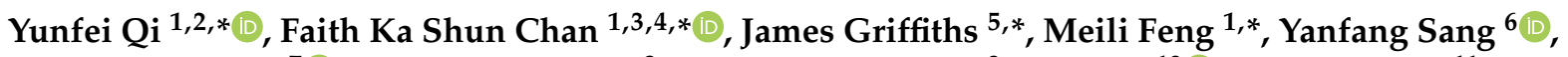 \\ Emily O'Donnell ${ }^{7} \mathbb{1}$, Michael Hutchins ${ }^{8}$, Dimple R. Thadani ${ }^{9}$, Gang Li ${ }^{10} \mathbb{D}$, Mengqi Shao ${ }^{11}$, Linjun Xie ${ }^{12}{ }^{(0)}$, \\ Sitong Liu ${ }^{1}$, Chunguang Zhang ${ }^{2}$, Xinan Li ${ }^{2}$, Lingyun Liu ${ }^{2, *}$ and Ming Zhong ${ }^{2}$
}

1 School of Geographical Sciences, University of Nottingham Ningbo China, Ningbo 315100, China; Liu.Sitong@nottingham.edu.cn

2 Guizhou Water \& Power Survey—Design Institute Co., Ltd., Guiyang 550002, China; gyzcg116@126.com (C.Z.); lixinan1985@126.com (X.L.); zhongminghhu@163.com (M.Z.)

3 School of Geography, University of Leeds, Leeds LS2 9JT, UK

$4 \quad$ Water@Leeds Research Institute, University of Leeds, Leeds LS2 9JT, UK

5 National Institute of Water \& Atmospheric Research (NIWA), Christchurch 8602, New Zealand

6 Key Laboratory of Water Cycle and Related Land Surface Processes, Institute of Geographic Sciences and Natural Resources Research, Chinese Academy of Sciences, Beijing 100101, China; sangyf@igsnrr.ac.cn

7 School of Geography, University of Nottingham, Nottingham NG7 2RD, UK; emily.o'donnell@nottingham.ac.uk

8 UK Centre for Ecology and Hydrology, Maclean Building, Benson Lane, Crowmarsh Gifford, Wallingford, Oxford OX10 8BB, UK; mihu@ceh.ac.uk

9 Nottingham University Business School, University of Nottingham Ningbo China, Ningbo 315100, China; Dimple.Thadani@nottingham.edu.cn

check for updates

Citation: Qi, Y.; Shun Chan, F.K.; Griffiths, J.; Feng, M.; Sang, Y.; O'Donnell, E.; Hutchins, M.; Thadani, D.R.; Li, G.; Shao, M.; et al. Sponge City Program (SCP) and Urban Flood Management (UFM)-The Case of Guiyang, SW China. Water 2021, 13 2784. https://doi.org/10.3390/ w13192784

Academic Editor: Leonardo V. Noto

Received: 21 July 2021

Accepted: 28 September 2021

Published: 8 October 2021

Publisher's Note: MDPI stays neutral with regard to jurisdictional claims in published maps and institutional affiliations.

Copyright: (C) 2021 by the authors. Licensee MDPI, Basel, Switzerland. This article is an open access article distributed under the terms and conditions of the Creative Commons Attribution (CC BY) license (https:// creativecommons.org/licenses/by/ $4.0 /)$.
10 Institute of Urban Environment, Chinese Academy of Sciences, Xiamen 361021, China; gli@iue.ac.cn

11 Faculty of Humanities and Social Sciences (FHSS), University of Nottingham Ningbo China, Ningbo 315100, China; Mengqi.Shao@nottingham.edu.cn

12 Department of Architecture and Built Environment, University of Nottingham Ningbo China, Ningbo 315100, China; Linjun-xie@nottingham.edu.cn

* Correspondence: yunfei.qi@nottingham.edu.cn (Y.Q.); faith.chan@nottingham.edu.cn (F.K.S.C.); James.Griffiths@niwa.co.nz (J.G.); meili.feng@nottingham.edu.cn (M.F.); liulingyun901023@126.com (L.L.)

Abstract: Flood management is a complex issue in Chinese cities that exhibit high populations and have undergone rapid urbanization. Urban flood management (UFM) approaches can be used to mitigate urban flood risk. To address urban issues of poor water quality and urban surface flooding, the Sponge City Program (SCP) was initiated in 2013 in China. The SCP aims to provide an opportunity for Chinese cities to improve their current UFM practices. This study looks at Guiyang (a pilot sponge city located in SW China) as a case study to identify the challenges and opportunities of UFM in China. Guiyang is a valley city surrounded by a hilly landscape. Using interview records and flood data, we illustrate that the primary type of flood in Guiyang is fluvial rather than surface water flooding. In Guiyang, the current function and targets of the SCP have yet to engage with the catchment level flood management, instead mainly focusing on the site-specific context (i.e., community level). Catchment flood management planning (CFMP) and natural flood management (NFM) both address this problem and may be a more suitable approach to manage flood discharge from the upper and middle catchments in Guiyang. In addition, it is suggested that a mixed option combining "hard" infrastructure (e.g., reservoirs and floodwalls) with "soft" flood management measures (e.g., improving people awareness and participation) may improve urban flood resilience in Chinese cities.

Keywords: catchment flood management plan (CFMP); urban flood management (UFM); natural flood management (NFM); Sponge City Program (SCP); urban flood resilience; Guiyang 


\section{Introduction}

The process of worldwide urbanization has accelerated rapidly [1], and global climate change has also become more apparent in the past century [2]. Urbanization has exacerbated the damaging consequence of climate change, such as more frequent flooding events [3]. For example, flooding events have increased in Chinese cities as a result of climate change and urbanization [4]. Previously, flood policy and management were both engineering-centric in China [5].

In 2013, the initiation of the Sponge City Program (SCP) provided an opportunity for planners and engineers in China to develop a sustainable approach to urban flood management (UFM) by greater use of SCP measures (e.g., wetland parks, ponds, and rain-gardens) [6]. The purpose, function, and technologies of SCP were partly unknown by local decision-makers during the first stage of the SCP (2015 to 2018). Thus, National Government selected Gui'an New District (i.e., one of Guiyang's districts) as a pilot study in 2016 to implement the SCP and better understand the efficiency of SCP in addressing the flood issues [7].

At the initial stage of SCP, most policymakers and engineers thought SCP measures could effectively solve flood issues, including pluvial and fluvial floods. In this case study, we interviewed stakeholders to understand whether grey infrastructure and the SCP adequately address flood risks in Guiyang. We illustrated that the SCP was not ideally designed to protect against catchment-scale fluvial floods [8]. The SCP measures mainly focused on local pluvial issues at the district scale. Suppose cities are at risk from catchmentscale fluvial flooding. In this case, it is often necessary for grey infrastructure (e.g., dams) to store upstream rainwater and reduce the resulting downstream flood peak [9]. Besides the SCP, the current UFM needs to be in conjunction with a catchment-scale catchment flood management plan (CFMP) and natural flood management (NFM) [10].

We chose semi-structured interview (SSI) and focus group approach (FGA) methods in the Guiyang case study. We also found some governmental reports and data for crossvalidation. The objectives of this research were as follows: (1) identify current UFM strategies by illustrating flood management practice; (2) understand the role of the SCP in UFM; and (3) the results, discussions, and lessons learned from this case may help drive CFMP and NFM forward in other Chinese cities.

\section{Background-Development of Urban Flood Management (UFM) in China}

China has established a "grey" flood management system by integrating reservoirs, dykes, river channels, and water gates in the last few decades. In 1949, there were only 1200 reservoirs in China. By 2018, China had built over 98,822 reservoirs, 312,000 km of dykes, and 104,403 water gates. The total water storage capacity of the reservoirs was 895.3 billion $\mathrm{m}^{3}$ [11]. The dykes and water gates could protect 630 million people and 41 million hectares of cropland [12].

There are three periods of UFM in China [13], of which the first stage started in the 1950s. The Chinese National Government realized the importance of building water infrastructure. Because of technology and investment limitations during the 1950s, it was not easy to implement. There were only 2301 reservoirs constructed by 1957, which was far from enough to protect the large population and expanse of managed land. The reservoirs were rapidly increased to 86,822 in 1980. After the 1980s, the number of newbuild reservoirs increased steadily [14]. Most mega reservoirs, such as the Three Gorges Dam and Longtan Reservoir, were built after the 1990s. The second stage began in the 2000s when China implemented urban rainfall utilization projects. After the 2010s, China began to explore new generation UFM. After the 2010s, China initiated the SCP inspired by the concepts associated with low impact development (LID) [15]. Since then, China has reached the third stage of UFM (i.e., integrated stormwater management) against the background of the SCP (Figure 1). 


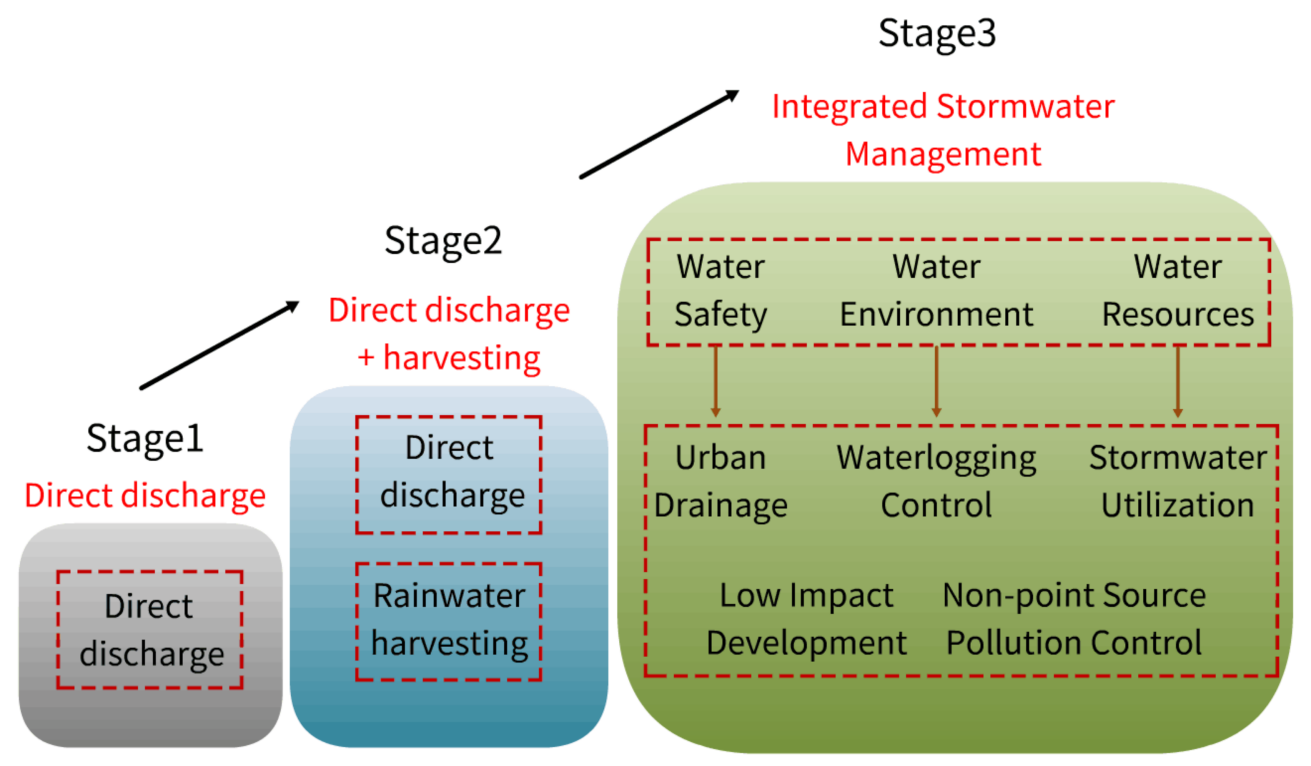

Figure 1. Development of urban flood management (UFM). Drawn by authors.

In December 2013, the Chinese National Government initiated the construction of Sponge Cities to address urbanization issues (e.g., pluvial flooding) and improve people's quality of life [7]. In March 2014, the National Government restated that urban planning and construction must reduce the intensity to preserve and restore ecological space as a buffering 'Sponge Space'. In November 2014, the Ministry of Housing and Urban-Rural Development issued the "Technical Guide for Construction of Sponge City (Trial)" as the first technical guide for the SCP [16]. The guide suggested that future cities should restore and simulate the natural water cycle to improve urban resilience and help adapt to climate change and reduce urban flooding. In August 2015, the Ministry of Water Resource issued "An Opinion of Implementing Water Project in Sponge City". The governmental document pointed out that the potential role of Sponge City structured with urban green space, wetland, river, and lake is to improve water penetration and purification [11].

A series of national policies have also been developed alongside the UFM strategies. "The National Water Law" was first formulated in 1988 (then revised in 2002 and 2016). This enactment provided the earliest legal evidence of water management [17]. In 1989, the State Council issued "The Announcement of Strengthening Urban Flood Control Works" to officially require the formulation of urban flood planning [18]. In 1990, the Ministry of Water Resources published "The Outline of Urban Flood Control Planning" [19] to clarify the contents of urban flood planning. To tie in with the water law and flood planning, the National Government promulgated "The National Flood Control Law" in 1997 (revised in 2007) [20]. In 2011, the General Office of Flood Defense issued “The Notice of Strengthening Urban Flood Control Planning" to highlight the importance of urban flood planning in coping with the ongoing challenges of rapid urbanization and climate change [21]. Meanwhile, "The National Law of Urban and Rural Planning" (issued in 1986 and revised in 1988, 2004, and 2019) [22] and "The National Land Management Law" (published in 1987 and revised in 1988, 2004, and 2019) also set requirements that urban planning and land use should match up with urban flood management [23]. Table 1 summarizes the development of UFM in China. 
Table 1. The development of UFM in Guiyang. Adopted by authors.

\begin{tabular}{|c|c|c|c|c|c|}
\hline \multirow{2}{*}{ Elements } & \multicolumn{5}{|c|}{ Time } \\
\hline & Before 1950 & 1950-1980 & 1980-1995 & 1995-2010 & 2010-Now \\
\hline $\begin{array}{l}\text { Flood management } \\
\text { strategy }\end{array}$ & $\begin{array}{c}\text { There were few } \\
\text { large and } \\
\text { medium-sized } \\
\text { water conservancy } \\
\text { projects. }\end{array}$ & $\begin{array}{l}\text { The government } \\
\text { began to build } \\
\text { reservoirs on } \\
\text { urban upstream } \\
\text { reaches. }\end{array}$ & $\begin{array}{l}\text { The government } \\
\text { began to build } \\
\text { floodwall and } \\
\text { levees on urban } \\
\text { upstream reaches. }\end{array}$ & $\begin{array}{l}\text { The urban } \\
\text { drainage system } \\
\text { has been gradually } \\
\text { improved, but the } \\
\text { standard is still } \\
\text { low (1-in-1 to } \\
\text { 1-in-5 years). }\end{array}$ & $\begin{array}{c}\text { Starting to } \\
\text { implement natural } \\
\text { flood management } \\
\text { (e.g., SCP). }\end{array}$ \\
\hline Measures options & $\begin{array}{c}\text { No flood } \\
\text { management } \\
\text { strategy was } \\
\text { evident. }\end{array}$ & $\begin{array}{l}\text { A fluvial-source } \\
\text { strategy focusing } \\
\text { on control flood } \\
\text { source }\end{array}$ & $\begin{array}{l}\text { A river-reaches } \\
\text { approach focusing } \\
\text { on preventing } \\
\text { fluvial flood on } \\
\text { urban reaches }\end{array}$ & $\begin{array}{l}\text { An inner-urban } \\
\text { strategy aiming to } \\
\text { solve urban } \\
\text { pluvial issues }\end{array}$ & $\begin{array}{l}\text { An ecological } \\
\text { strategy to } \\
\text { improve landscape } \\
\text { and peoples' } \\
\text { well-being and } \\
\text { reduce flood risk }\end{array}$ \\
\hline Investment source & $\begin{array}{c}\text { Lack of financial } \\
\text { support }\end{array}$ & $\begin{array}{l}\text { Government } \\
\text { investment }\end{array}$ & $\begin{array}{l}\text { Government } \\
\text { investment }\end{array}$ & $\begin{array}{l}\text { Government } \\
\text { investment }\end{array}$ & $\begin{array}{l}\text { A public and } \\
\text { private partnership } \\
\text { investment model }\end{array}$ \\
\hline $\begin{array}{l}\text { Climate change } \\
\text { consideration }\end{array}$ & No & No & $\begin{array}{c}\text { Major } \\
\text { consideration of } \\
\text { the local } \\
\text { meteorological and } \\
\text { flood } \\
\text { characteristics }\end{array}$ & $\begin{array}{c}\text { Major } \\
\text { consideration of } \\
\text { the local } \\
\text { meteorological and } \\
\text { flood } \\
\text { characteristics }\end{array}$ & $\begin{array}{l}\text { Starting to realize } \\
\text { the significant } \\
\text { impact of global } \\
\text { climate change. }\end{array}$ \\
\hline $\begin{array}{c}\text { Public } \\
\text { participation }\end{array}$ & $\begin{array}{l}\text { All projects were } \\
\text { government-led, } \\
\text { limited public } \\
\text { participation. }\end{array}$ & $\begin{array}{l}\text { All projects were } \\
\text { government-led. }\end{array}$ & $\begin{array}{l}\text { All projects were } \\
\text { government-led. }\end{array}$ & $\begin{array}{l}\text { Most projects were } \\
\text { government-led, } \\
\text { but public } \\
\text { participation is } \\
\text { limited. }\end{array}$ & $\begin{array}{c}\text { The National } \\
\text { Government } \\
\text { started to realize } \\
\text { the importance of } \\
\text { stakeholders' } \\
\text { participation, but } \\
\text { most projects were } \\
\text { still a } \\
\text { government-led } \\
\text { model. }\end{array}$ \\
\hline $\begin{array}{l}\text { Emergency } \\
\text { planning and } \\
\text { management }\end{array}$ & $\begin{array}{l}\text { No systematic } \\
\text { emergency rescue } \\
\text { system. }\end{array}$ & $\begin{array}{l}\text { No systematic } \\
\text { emergency rescue } \\
\text { system. }\end{array}$ & $\begin{array}{l}\text { No systematic } \\
\text { emergency rescue } \\
\text { system. }\end{array}$ & $\begin{array}{l}\text { An early warning } \\
\text { system based on } \\
\text { meteorological } \\
\text { forecasts was set } \\
\text { up, but it was } \\
\text { difficult to realize } \\
\text { the real-time flood } \\
\text { warning function. } \\
\text { Each department } \\
\text { independently } \\
\text { carried out various } \\
\text { disaster relief. For } \\
\text { example, the water } \\
\text { department was } \\
\text { responsible for } \\
\text { flood relief, and } \\
\text { the fire department } \\
\text { was responsible for } \\
\text { fire relief. }\end{array}$ & $\begin{array}{l}\text { A comprehensive } \\
\text { emergency rescue } \\
\text { system and rescue } \\
\text { team was initially } \\
\text { established. }\end{array}$ \\
\hline
\end{tabular}

\section{Methodology}

In this paper, we chose semi-structured interview (SSI) and focus group approach (FGA) as qualitative methods in the Guiyang case, a pilot Sponge City. We also identified 
and invited stakeholders such as officials, engineers, and residents as interviewees to find out their perspectives and comments on UFM and SCP.

\subsection{Case Study}

Guiyang is located on the Yunnan-Guizhou Plateau, SW China. The city has a typical sub-plateau valley terrain with an average altitude of $1100 \mathrm{~m}$ (Figure 2a). The Nanming River passes through the whole city (Figure $2 b$ ), which makes the city a flood-prone area [24]. Guiyang is also one of the first-batch pilot Sponge Cities. It has also implemented many 'grey' and SCP infrastructures owing to the current rapidly developing economy. The research results, discussions, and suggestions in Sections 4 and 5 may help identify current UFM strategies; understand the role of the SCP in UFM under the background of the mountainous city; and drive CFMP and NFM forward in other mountainous areas Chinese cities such as Chongqing, Kunming, and Chengdu.

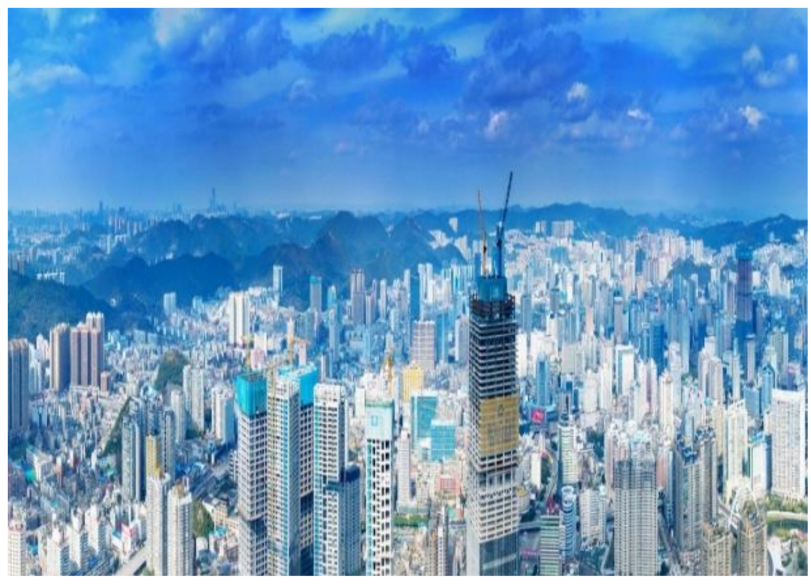

(a)

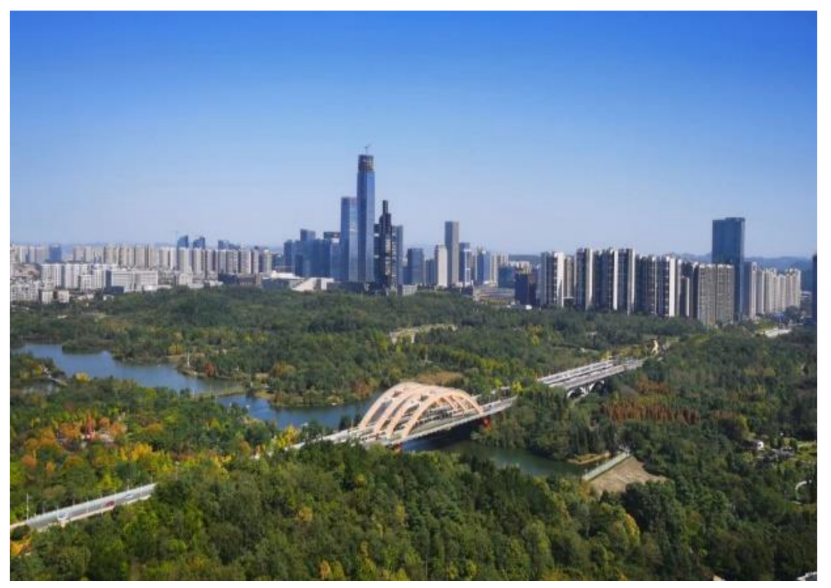

(b)

Figure 2. (a) Mountainous terrain of Guiyang; (b) Nanming River in Guiyang CBD. Photographed by the authors.

Guiyang is one of the fastest developing cities in China, and it plays a central role in the "Central Guizhou Economic Zone" and "Pan-Pearl River Delta Economic Circle" [25]. Guiyang has maintained high economic and population growth in recent years. Between 1990 and 2019, the urbanized area increased from $43.9 \%$ to $75.4 \%$ [26]. However, rapid urbanization has increased the flood risk owing to greater centralization of population and properties. The urban runoff rate has reached $70 \%$ on account of increasing impermeable urban surfaces [8]. The current discharge capacity of the urban stormwater system is just at a return period of 5 years, which cannot meet the current requirement of UFM [27]. Since the SCP initiation, the Guiyang Municipal Government has accelerated new generation UFM to improve flood resilience [28].

Following the national laws mentioned in Section 2, the Guizhou Provincial Government also compiled regulations to address local flood issues. For example, "Guizhou Provincial Regulation for Flood Control" was issued in 2003 (revised in 2004, 2015, and 2017) [29]. "Guizhou Provincial Regulation for River Administration" was published in 1997 (revised in 2004 and 2019) [30]. The Guiyang Municipal Government also legislated regulations such as "Guiyang Municipal Regulation for Flood Control" (published 1996, revised in 2006) [31] and "Guiyang Municipal Regulation for River Administration" (published in 1997, revised in 2004) [32] to address urban flood issues in Guiyang. However, the investigational evidence of whether the $\mathrm{SCP}$ has addressed urban flood issues in Guiyang is still lacking. In the context of the $\mathrm{SCP}$, Guiyang needs more innovative approaches to further improve UFM practices. 


\subsection{Research Design}

We used interview methods to identify issues and find potential solutions related to UFM. The classic interview methods can be classified as structured interview (SI), semi-structured interview (SSI), unstructured interview (UI), and focus group approach (FGA) [33]. The SI is a rigorous interview method with a fully prepared question list. The whole interview is conducted with a plan. All questions given to interviewees are the same. The advantage of SI is that it is easy to code for data research. The disadvantage of SI is that, if interviewers lack sufficient knowledge and experience to set a professional question list, the interview may lose information [34]. On the other side, the UI is a method with "freestyle" [35]. It does not require a question list in advance. It can create a friendly and comfortable talking environment to achieve deep thinking in interviewees. However, the UI requires the interviewers have enough professional experience and adaptability on topics to different interviewees. The SSI has characteristics of both SI and UI. The SSI needs a general question guideline to be prepared. The guideline only provides a general orientation for interviewers. The SSI helps interviewers gather core and sensitive information in a relaxed communicational process [36]. The FGA is a method of group interviews. A host invites a group of targeted people to exchange ideas in meetings or activities. It allows participators to discuss with each other following planned guideline topics.

This study aims to understand viewpoints from officials, communities, and residents. The reason this study picked SSI and FGA is to identify the issues in-depth. Through SSI, we could explicitly extract the concerns from professional perspectives, such as governmental officials, water engineers, and urban planners, and boost up the professionalism and depth of the information sources from the case of Guiyang [37]. In these depth discussions via SSI, interviewers could efficiently collect critical information. The SSI also strengthened the argument in this manuscript to understand whether the past UFM practice and current SCP approaches might have any barriers, limitations, and opportunities ahead. Because we are not targeting the specific demographic changes (populations, ages, and genders) and issues that might require justification via a large-scale questionnaire survey, the questionnaire surveys are not applicable in this study. We used FGA to target specific interviewees to understand the issues in-depth, such as residents who settle surrounding rivers. The characteristics of FGA do not necessarily require too many interviewees.

Therefore, in this research, we categorized interviewees into two categories. We invited very experienced officials, top engineers, and residents aged 40 to 70 . These participants are very representative in flood management, techniques, and events (Table 2). The first category of respondents included 10 very experienced officials from Guiyang Municipal Government, the Water Conservancy Bureau, the Natural Resources Bureau, the Emergency Management Bureau, the Urban Construction Bureau, and another four top engineers in urban planning and water engineering. The second category included 20 residents who lived along the Nanming River (Table 2 and Figure 3). We also prepared a list of the most frequent themes to structure the interviews (Table 2). 
Table 2. Interviewees and IDs.

\begin{tabular}{|c|c|c|c|c|c|c|}
\hline Respondents & Bureau/Department & Respondent ID & Position & Professional Title & Age & Main Questions \\
\hline \multirow{9}{*}{ 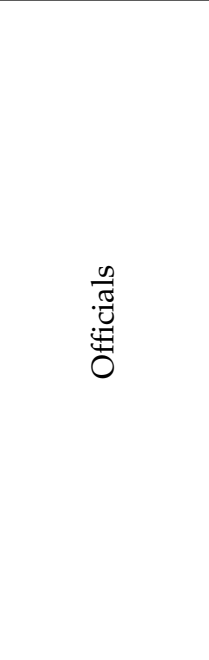 } & \multirow{2}{*}{ Municipal Government } & A & Secretary General & $\backslash$ & 50 & \multirow{13}{*}{$\begin{array}{l}\text { (1) What is the leading cause of the most } \\
\text { significant flood in Guiyang? (2) What is the } \\
\text { status of the flood projects in the Nanming River } \\
\text { Basin? (3) Please describe the developing } \\
\text { conditions of the SCP in Guiyang. (4) What is the } \\
\text { design standard of the sewers of Guiyang? Can } \\
\text { this designing standard meet flood control } \\
\text { needs? (5) What do you think is the leading } \\
\text { cause of the flood disaster in Guiyang? (6) Please } \\
\text { briefly introduce the relationship between SCP } \\
\text { and flood projects. (7) Please introduce the } \\
\text { success or failure of emergency management in } \\
\text { Guiyang. (8) What is the level of public } \\
\text { awareness of flood hazards? (9) Are there many } \\
\text { opportunities for the public to participate in } \\
\text { urban planning, engineering design, and } \\
\text { policymaking? What are the ways to participate? } \\
\text { (10) Please briefly introduce your suggestions on } \\
\text { urban flood management, catchment flood } \\
\text { management, and SCP. }\end{array}$} \\
\hline & & B & $\begin{array}{c}\text { Deputy Secretary } \\
\text { General }\end{array}$ & $\backslash$ & 45 & \\
\hline & Bureau & $\mathrm{D}$ & Chief Engineer & Senior Engineer & 50 & \\
\hline & Natural Resources & $\mathrm{E}$ & $\begin{array}{c}\text { Deputy Director } \\
\text { General }\end{array}$ & Senior Engineer & 55 & \\
\hline & Bureau & $\mathrm{F}$ & $\begin{array}{l}\text { Deputy Chief } \\
\text { Engineer }\end{array}$ & Senior Engineer & 50 & \\
\hline & Emergency Management & G & $\begin{array}{l}\text { Deputy Director } \\
\text { General }\end{array}$ & Senior Engineer & 48 & \\
\hline & Bureau & $\mathrm{H}$ & $\begin{array}{l}\text { Deputy Chief } \\
\text { Engineer }\end{array}$ & Senior Engineer & 45 & \\
\hline & Urban Construction & I & $\begin{array}{l}\text { Deputy Director } \\
\text { General }\end{array}$ & Senior Engineer & 45 & \\
\hline & & $\mathrm{J}$ & $\begin{array}{c}\text { Deputy Chief } \\
\text { Engineer }\end{array}$ & Senior Engineer & 50 & \\
\hline \multirow{4}{*}{ 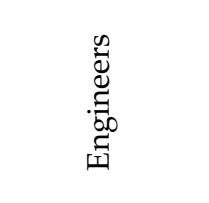 } & \multirow{2}{*}{$\begin{array}{l}\text { Urban Planning } \\
\text { Engineers }\end{array}$} & K & $\begin{array}{c}\text { Deputy General } \\
\text { Manager }\end{array}$ & Senior Engineer & 50 & \\
\hline & & $\mathrm{L}$ & Project Manager & Senior Engineer & 42 & \\
\hline & & M & General Manager & Senior Engineer & 58 & \\
\hline & & $\mathrm{N}$ & Project Manager & Senior Engineer & 43 & \\
\hline \multirow[t]{4}{*}{ 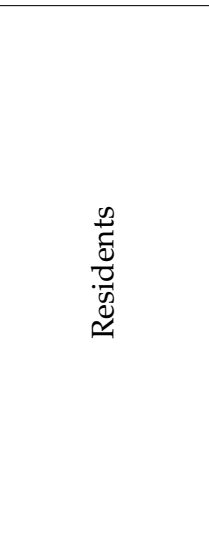 } & 1 & $\mathrm{a} \sim \mathrm{e}$ & 1 & $\backslash$ & $40 \sim 55$ & $\begin{array}{l}\text { (1) When did you experience an enormous flood? } \\
\text { (2) What other major floods have you } \\
\text { experienced except for the most significant flood } \\
\text { event? (3) How did these floods affect your life? } \\
\text { (4) Do you remember which landmarks } \\
\text { submerged in previous floods? What did you } \\
\text { suffer from the flood you experienced? (5) What } \\
\text { do you think of the local government's rescue } \\
\text { efforts? (6) Do you have any emergency relief } \\
\text { supplies in your home? (7) Do you know } \\
\text { anything about emergency rescue knowledge? }\end{array}$ \\
\hline & & $f \sim j$ & 1 & 1 & $55 \sim 60$ & How do you know this? (8) What \\
\hline & & $\mathrm{k} \sim \mathrm{o}$ & 1 & 1 & $60 \sim 65$ & recommendations do you have about \\
\hline & & $\mathrm{p} \sim \mathrm{t}$ & 1 & 1 & $65 \sim 70$ & flood management? \\
\hline
\end{tabular}




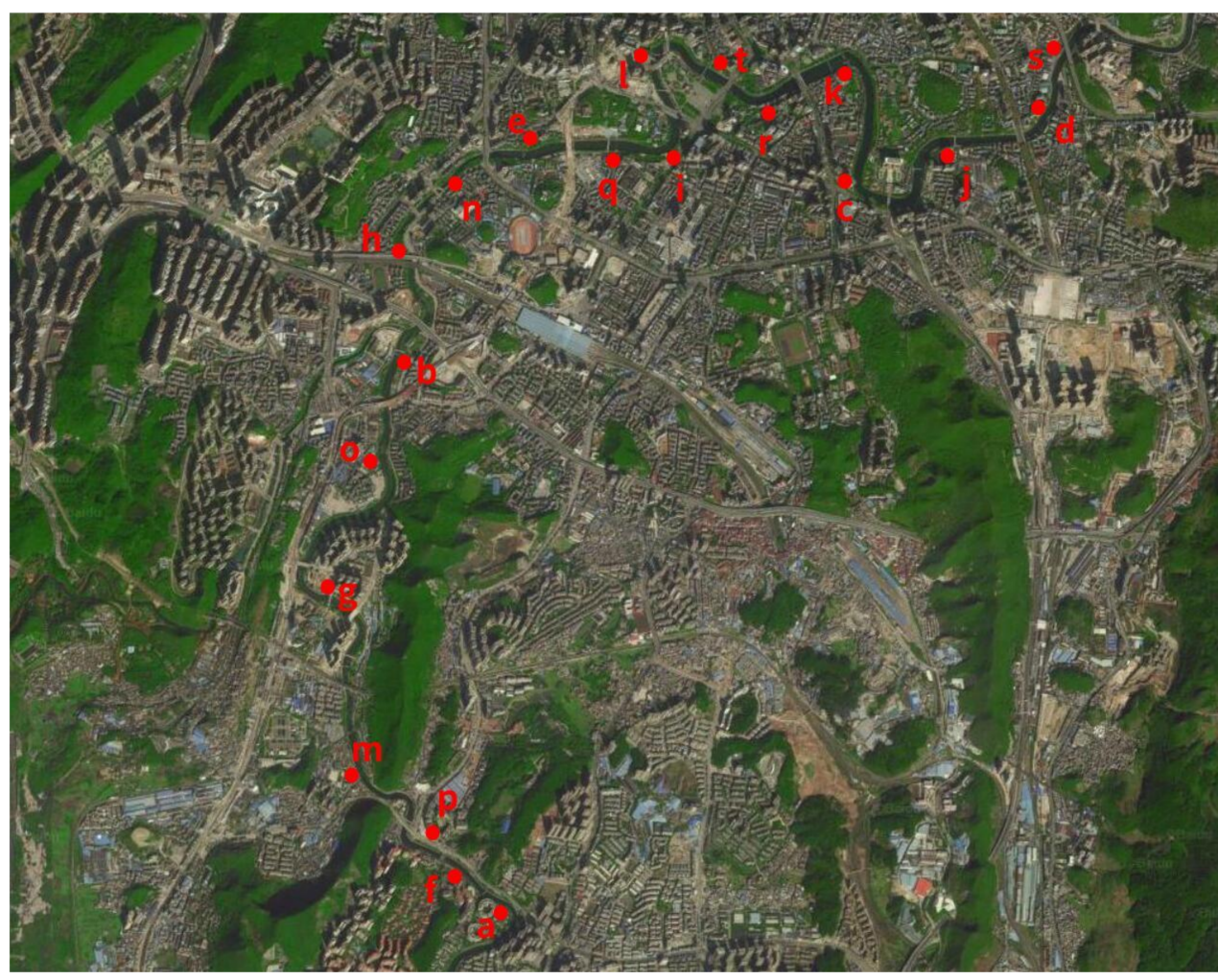

Figure 3. The locations of residents who joined the research.

In general, because some of the participants were from authorities (governmental officials) and professional institutes (engineers), we adopted the SSI method to decrease questions' sensitivity and increase the depth of interviews. Meanwhile, we chose FGA to improve the efficiency and depth of collecting specific people's awareness. Both SSI and FGA can accurately target interviewees in particular occupations and locations, making the interview process more effective and efficient.

Each interview and meeting took 30-45 min via face-to-face conversation, cellphone, and popular social online platforms in China such as WeChat and QQ. Most of the interviewees in this research enjoyed the communicational ways we selected. They were willing to give honest thoughts. All interviews were conducted in Mandarin and then translated to English for further coding by NVivo software. The research was previously reviewed and approved by the Faculty of Science and Engineering Research Ethics Committee at University of Nottingham Ningbo China (UNNC). All participants also agreed on the conduction of the research. All data were used anonymously. Secondary data from official reports and public news were used as triangulation to validate the data collected from SSI and FGA.

\section{Results}

\subsection{Grey Infrastructure in Urban Flood Management-The Case of Guiyang}

According to the governmental report, "Guiyang Water Supply and Discharge Special Plan for 13th Five-Year", the major flood events that have caused huge damage in history were all relative to the Nanming River [38]. The fluvial flooding events illustrated the flood characteristics of the city. The interviewees recalled the flooding history of Guiyang as follows:

"There were three remarkable flood events in my mind. They happened in summers of 1991, 1996 and 2014. The flood in 1991 mainly damaged lots of farmland due to the small urban scale at that time." (Interviewee a) 
"The flood in 1996 was most terrible in my mind. The heavy rainfall lasted two days. The water overflowed the riverbanks and submerged some landmarks, including Jiaxiu Pavilion (See Figure 4a) and Fountain Place. Many governmental bureaus, companies, and schools were closed three days. The flood damaged lots of houses and public facilities. The people's life was seriously affected by this flood." (Interviewee b)

"The rain was very intensive in 2014 as well. Fortunately, the flood did not affect us too much. The local government broadcasted the flood warning in advance. Although some roads were submerged by water (See Figure $4 b-d$ ), the city smoothly got through the flood event in 2014." (Interviewee c)

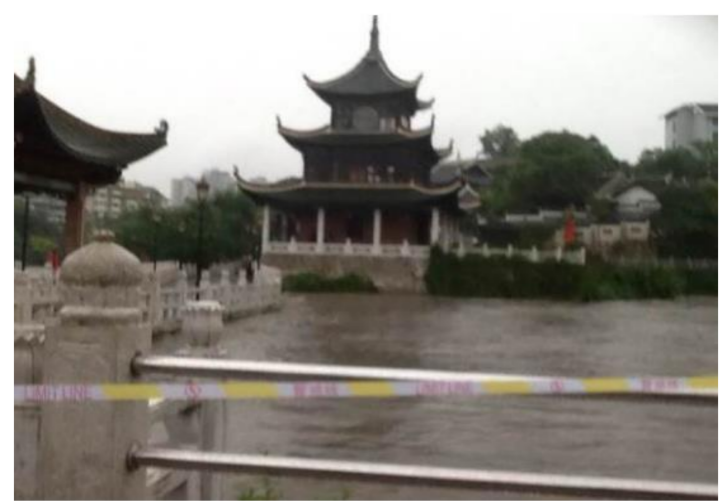

(a)

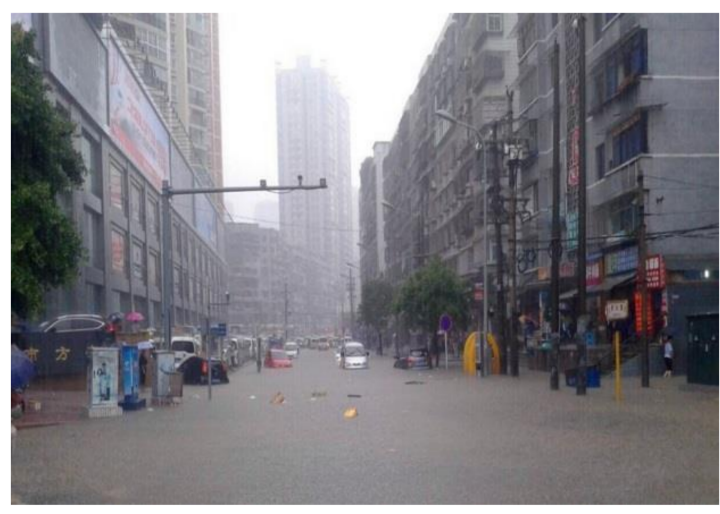

(c)

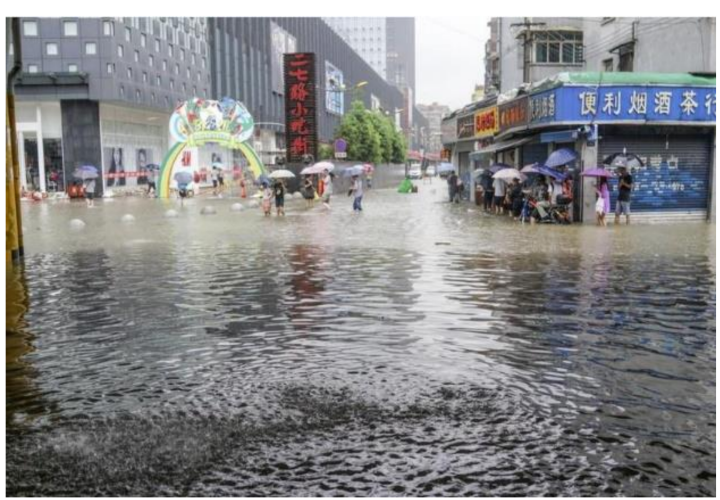

(b)

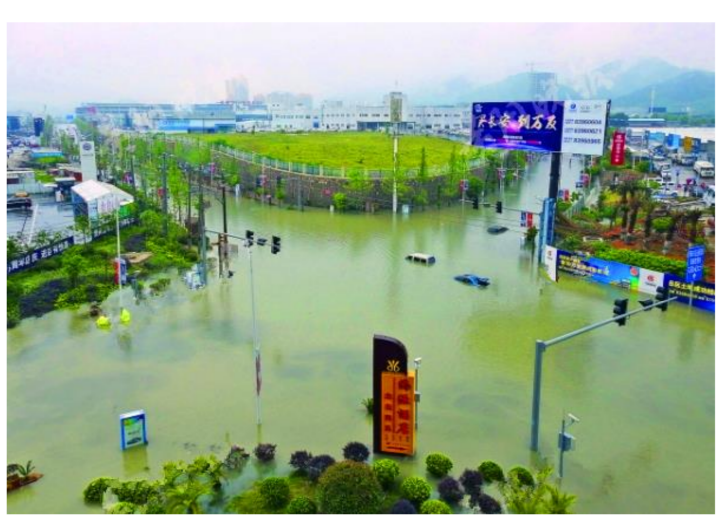

(d)

Figure 4. The 1996 floods in Guiyang. (a) Jiaxiu Pavilion; (b) Erqi Street; (c) Qingyun Road; (d) Mengguan. Photographed by the authors.

Governmental reports, such as the "Comprehensive Water Resources Planning for Guiyang", were used to validate the interview records of residents. On 1 July 1991, the fluvial flood at a return period of 5 years resulted in a total direct economic loss of 90 million RMB [39]. There was a significant loss on both sides of the Nanming River mainstream. The farm industry suffered a primary loss (58 million RMB) owing to the relatively undeveloped urban economy in the early 1990s. The flood was a typical two-peak fluvial flood caused by a rain with return period of 5 years $(112.0 \mathrm{~mm}$ in $24 \mathrm{~h}, 233.0 \mathrm{~mm}$ in $72 \mathrm{~h}, 305.0$ in $120 \mathrm{~h}$ ) [40]. The most damaging fluvial flood was caused by rain with a return period of 100 years on 2 July 1996 [38]. The flood was a one-peak fluvial flood caused by intensive rain (197.3 $\mathrm{mm}$ in $24 \mathrm{~h}$ ). The flood event affected over 929,022 people; 89 people died, 1124 were injured, and 8671 houses collapsed. The direct economic loss was 3.26 billion RMB, accounting for $11.8 \%$ of Guiyang's GDP in 1996 [39]. The rain intensity (201.7 $\mathrm{mm}$ in $24 \mathrm{~h}$, a return period of 100 years) on 16 July 2014 was slightly higher than the rain of 2 July 1996. Fortunately, the fluvial flood on 16 July 2014 caused more minor consequences. The flood 
depth was controlled under the top of the floodwalls. Most public infrastructures were safe to open, although parts of underground parking lots were flooded. There was no loss of life in this flood [26] (Table 3). All the precipitation and flood data are from Guiyang Weather Station and Guiyang Hydrological Station, respectively. The two stations are located in the center of Guiyang City, and nearby Nanming River. The Guiyang Weather Station uses classic gauge measures, including the tipping-bucket rain gauge. The Guiyang Hydrological Station uses the mechanical current-meter method and acoustic Doppler current profiler (ADCP) to measure the stream and flood. The two stations are the major and most authoritative in Guiyang and Nanming River Catchment. The officials and engineers explained the reasons for the difference in losses between the three flood events:

Table 3. Historical flood data of Guiyang. Adopted by authors.

\begin{tabular}{|c|c|c|c|c|c|c|c|}
\hline Rank & $\begin{array}{l}\text { Flooding } \\
\text { Date }\end{array}$ & Flood Type & $\begin{array}{l}\text { Flood Peak } \\
\left(\mathrm{m}^{3} / \mathrm{s}\right)\end{array}$ & $\begin{array}{c}\text { Precipitation } \\
\text { in } 24 \text { Hours } \\
(\mathrm{mm})\end{array}$ & $\begin{array}{c}\text { Direct } \\
\text { Economic } \\
\text { Losses } \\
\text { (Million } \\
\text { RMB) }\end{array}$ & $\begin{array}{c}\text { Houses } \\
\text { Have Been } \\
\text { Flooded }\end{array}$ & $\begin{array}{c}\text { Casualties } \\
\text { (People) }\end{array}$ \\
\hline 1 & 2 July 1996 & Fluvial flood & 878 & 197.3 & 3260 & $\begin{array}{c}8671 \\
\text { (collapsed) }\end{array}$ & 89 \\
\hline 2 & 1 July 1991 & Fluvial flood & 573 & 112.0 & 90 & $\begin{array}{c}\text { no statistics } \\
\text { parts of }\end{array}$ & / \\
\hline 3 & 16 July 2014 & Fluvial flood & 850 & 201.7 & 495 & $\begin{array}{l}\text { underground } \\
\text { parking lots }\end{array}$ & / \\
\hline
\end{tabular}

"The seasonal rain that covered the Nanming catchment was the main reason for flood events in Guiyang. The rainy frequency, length, and intensity on the Nanming catchment resulted in flooding consequence in Guiyang." (Interviewee A)

"There were two kinds of flood in Guiyang. The first was the fluvial flood, which caused huge damage to the riverside. Another is the regional pluvial event caused by the urban drainage system's relatively low design standard. The current drainage design standard can only protect a rain with return period of 5 years. The pluvial event mostly happened on a small scale, such as in communities, roads, and parking lots. The fluvial and pluvial events usually both occurred in one intensive rain. For example, the floods in 1991, 1996 and 2014." (Interviewee B)

"Comparing with small-scale pluvial events, the fluvial flood issue can result in huge losses to Guiyang. Therefore, flood management should focus more on catchment management. In the aspect, the upstream reservoirs, such as Huaxi Reservoir, Songbaishan Reservoir, and Aha Reservoir, play a critical role in the flood prevention." (Interviewee C)

The performance of grey infrastructures can be found in governmental reports, such as "The Flood Control Planning for Guiyang". In the 1960s-1970s, the UFM strategy focused on the grey strategy. The Huaxi Reservoir, Songbaishan Reservoir, and Aha Reservoir were built upstream Nanming River to water supply and flood control (Figure 5a-c). The three reservoirs have a total storage capacity of 146 million $\mathrm{m}^{3}$, covering a basin area of $515 \mathrm{~km}^{2}$, accounting for $68.4 \%$ of the whole urban area [24]. Considering the mountainous topography of Guiyang, the upstream fluvial flood is flashy in urban reaches [40]. The upstream reservoirs can reduce upstream flow by 30-70\% by rain with a return period of 100 years (i.e., the flood standard of Guiyang city) [41]. For instance, on 16 July 2014, the observed peak flow at the Guiyang Hydrological Station was $998 \mathrm{~m}^{3} / \mathrm{s}$ [42]. If the reservoirs had not been built in the upstream catchment, the peak flood flow would have reached up to $1522 \mathrm{~m}^{3} / \mathrm{s}$ on that day at Guiyang Hydrological Station $[40,43,44]$. The central city areas alongside the Naming River would have been fully inundated [40]. 


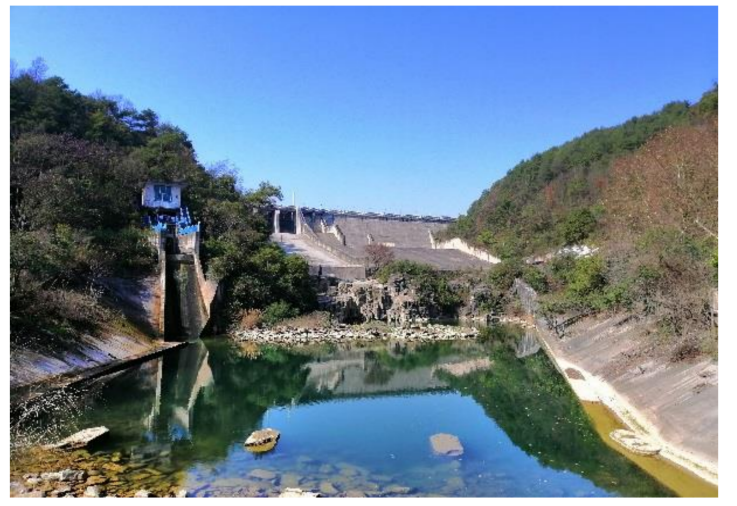

(a)

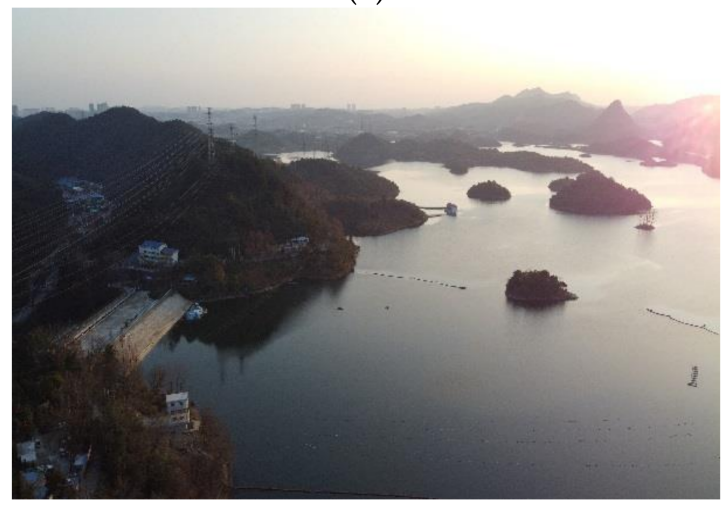

(c)

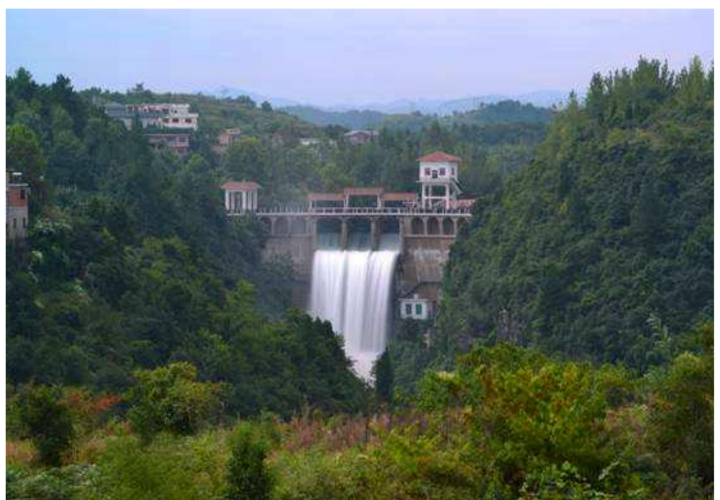

(b)

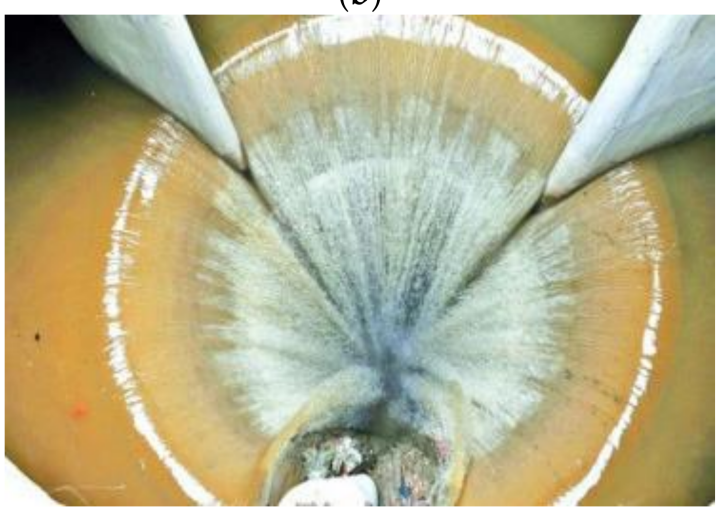

(d)

Figure 5. (a) Huaxi Reservoir; (b) Songbaishan Reservoir; (c) Aha Reservoir; (d) Inlet of Guan Cheng River Flood Tunnel. Photographed by the authors.

During the 1990s-2000s, the Guiyang Municipal Government kept setting up grey infrastructure. For example, $12 \mathrm{~km}^{2}$ floodwalls were built riverside [39]. In 1998, the Guiyang Municipal Government invested nearly 100 million RMB in building the Guan Cheng River Flood Distribution Tunnel (Figure 5d). The tunnel was open for operation in the early 2000s [42]. The $3.3 \mathrm{~km}$ underground tunnel provided $100 \mathrm{~m}^{3} / \mathrm{s}$ of flooddischarging ability, which was another main reason that the flood on 16 July 2014 caused less severe consequences than the 1996 event (the tunnel collected and discharged urban surface water directly into urban downstream reaches to protect the central urban area) [41]. Some water and civil engineers mentioned the contributions of grey infrastructure:

"Due to construction of flood wall (Figure 6a) and flood tunnel (Figure 6b) in the late 1990s, Guiyang successfully protected the city from the flood on 16 July 2014. After implementing Guan Cheng River Flood Tunnel, the central city hardly suffered huge losses of flood events." (Interviewees D).

"According to our engineering experiences, the most effective way to reduce flood risks in Guiyang is still using reservoirs (storing upstream flood), flood tunnels (discharging flood bypass the city area), flood wall (protecting riverside urban area from the flood). (Interviewees $M$ ). 


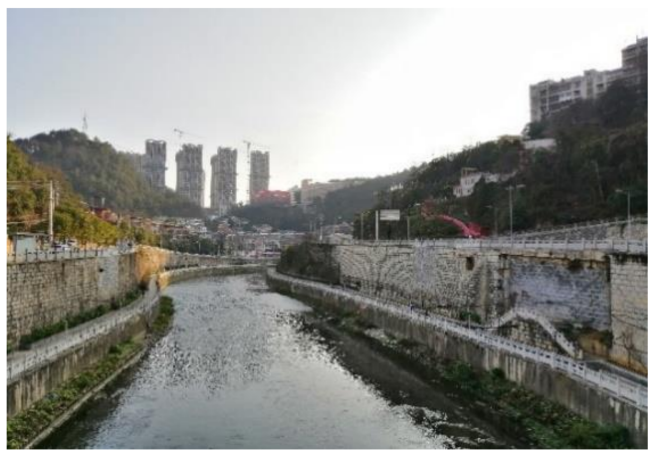

(a)

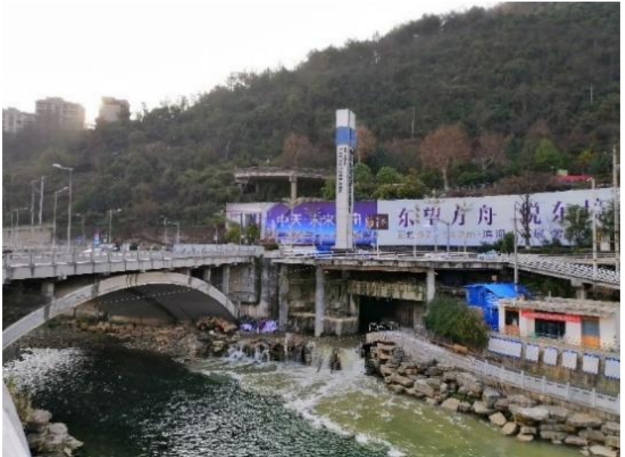

(b)

Figure 6. (a) Flood wall on urban reaches; (b) the outlet of the Guan Cheng River Flood Tunnel. Photographed by the authors.

\subsection{The Performance of SCP Infrastructures in UFM}

Following the national policies on SCP mentioned in Section 2, the Guiyang Municipal Government issued the "Sponge City Construction Implementation Plan" [45] and "The Sponge City Construction Planning of Guiyang Central City (2016-2030)" [46] in 2016. In 2019, the Guiyang Municipal Government established “The Sponge City Planning of Guiyang Central City (2019-2030)" [27]. Table 4 illustrates the Guiyang municipal government adopted construction codes and measures affiliated with Sponge City construction measures on urban planning (CJJ 83-2016), land drainage (GB 50400-2016), and stormwater management (GB 50318-2017), among others, as these codes of practice and legislated guidance demonstrated each selected that Sponge City, such as Guiyang, has collaborated with and followed the Sponge City Program from the Central National Government.

Table 4. Bureaus and websites. Adopted by authors.

\begin{tabular}{ccc}
\hline Bureau & Website & References \\
\hline Guiyang Municipal Government & http://www.guiyang.gov.cn/ & {$[47]$} \\
Guiyang Water Conservancy Bureau & http://swglj.guiyang.gov.cn/ & {$[48]$} \\
Guiyang Natural Resources Bureau & http://zyghj.guiyang.gov.cn/ & {$[49]$} \\
Guiyang Emergency & http://yjj.guiyang.gov.cn/ & {$[50]$} \\
Management Bureau & http://zhujianju.guiyang.gov.cn/ & {$[51]$} \\
\hline Guiyang Urban Construction Bureau &
\end{tabular}

Meanwhile, several SCP infrastructures, such as green buildings and wetland parks, were constructed in Guiyang in the 2010s. For example, the Municipal Government completed 12 Sponge roads (20 km in total) with permeable asphalt and concrete, 19 urban parks (4.75 km² in total) with SCP measures (e.g., sunken gardens), 16 residential communities with Sponge facilities (e.g., green roofs), and 9 artificial wetlands $\left(7.26 \mathrm{~km}^{2}\right.$ in total) [46]. The Guanshan Lake Park, Huaxi Wetland Park, Donglingsi Park, and Yueshan Lake Park have become "cyber landmarks" (Figure 7a-d). However, the officials and residents expressed some concerns about the flood prevention capacity of SCP infrastructure:

"Currently, the SCP has partly improved urban flood protection standard to 30-year flood. But the SCP infrastructures were implemented on a small scale, such as rain gardens in communities, compared to the whole city scale of $380 \mathrm{~km}^{2}$. The SCP infrastructures did not show a very satisfactory capacity of flood prevention as expected. For example, Guanshan Lake Park, newly constructed in the 2010s, is a typical artificial wetland park. The Guanshan Lake Park and surrounding streets were totally submerged by intensive rainfall on 16 July 2014." (Interviewee G).

"When the rain is moderate, the green gardens and wetland parks can hold the initial rainwater. If the intensive rainfall occurred, or the rainy duration was over three 
days, the water could rush out from the wetlands to submerge the nearby urban areas."

(Interviewee e).

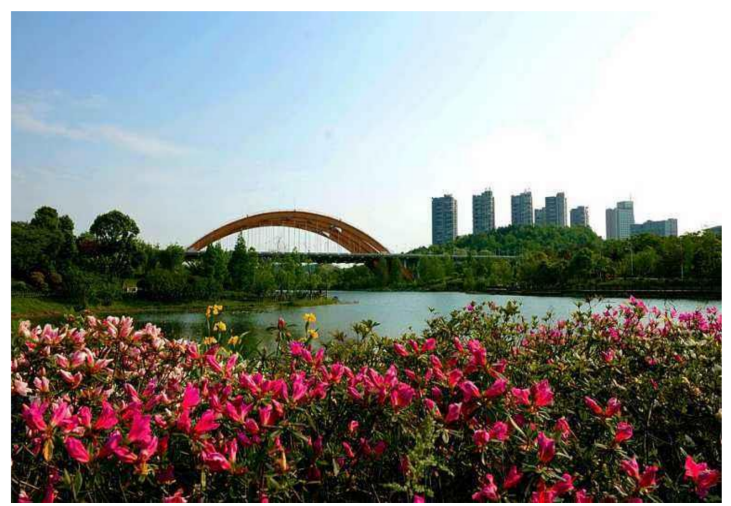

(a)

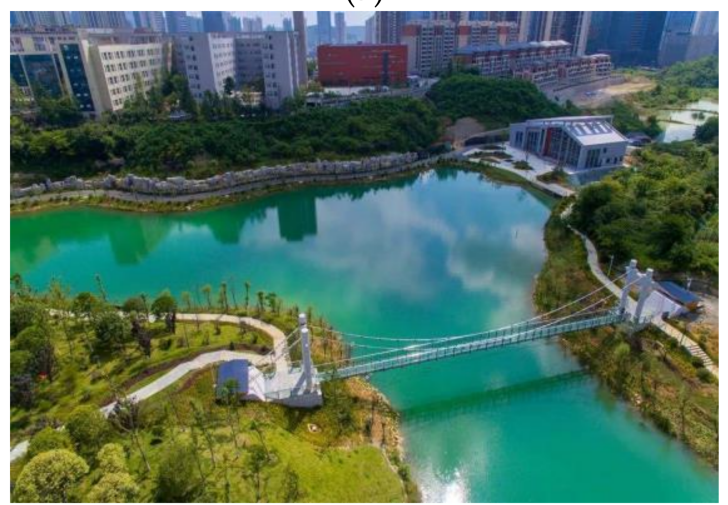

(c)

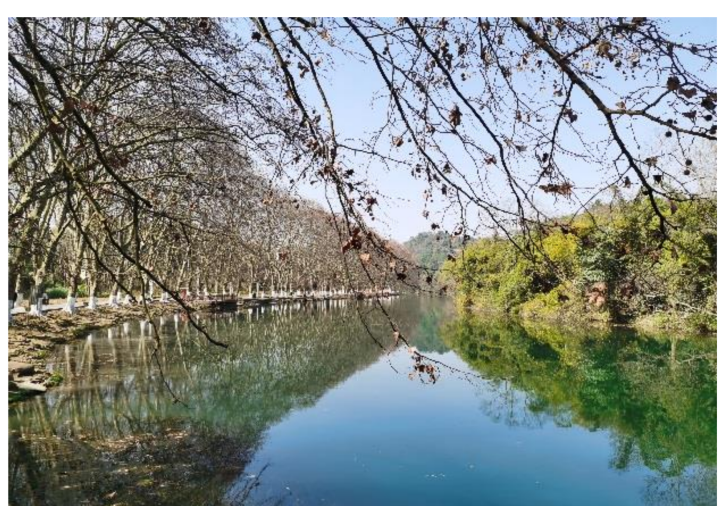

(b)

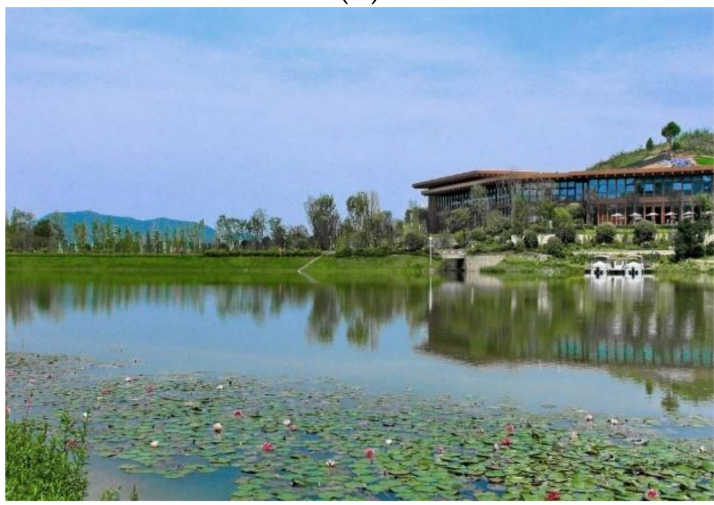

(d)

Figure 7. (a) Guanshan Lake Park; (b) Huaxi Wetland Park; (c) Dongling Park; (d) Yueshan Lake Park. Photographed by the authors.

The reasons could also be found in governmental reports such as "The Construction Planning of Flood Control Infrastructures for Guiyang" [42]. The water storage capacity of Guanshan Lake is only 0.15 million $\mathrm{m}^{3}$, which is far less than a medium reservoir (the water storage ability is more than 10 million $\mathrm{m}^{3}$ ). This means that the SCP infrastructure has a lower capacity to store upstream floodwaters. Meanwhile, compared with other major cities in Asia (e.g., Hong Kong and Singapore have 1-in-50 years flood standard in urban drainage system) [52], Guiyang needs to improve the current urban drainage system connected to SCP infrastructures [42]. The residents and engineers typically stated the following:

"Branches, trash, and dirt easily blocked the urban drainage system. The maintenance services on the urban drainage system are inadequate. The blocked urban drainage system could stem the water from discharge, which may cause the pluvial events". (Interviewee f)

"The current urban drainage system connected with SCP infrastructures is aged. It is outdated with relatively low designing standards. It can only protect a rain with return period of 5 years. The urban drainage system cannot cope with the current requirement of flood management." (Interviewee H)

According to the interviews and secondary data, grey infrastructure is more effective in dealing with the fluvial floods, as discussed in Guiyang, especially under catchmentsized intensive rainstorms. Furthermore, it is crucial to revise and improve codes and standards to increase the flood standard of the urban drainage system to deal with urban flood issues. 


\subsection{People's Awareness}

In the case of Guiyang, people's awareness was explored to understand the risk judgments for different hazards, the relationships between the SCP and flooding, and knowledge of self-protection measures. The SSI and FGA showed that $45 \%$ of participants believed flooding was a significant hazard in Guiyang. Most middle- and old-aged people had clear memories of the flood in 1996. The second rank was landslide hazard; $25 \%$ of participates felt that the landslide hazard was the most frequent in Guiyang, and fire was the third-highest ranked. Although most people had seen or experienced a building fire in the past, only $15 \%$ of people thought fire was the primary hazard. Earthquakes ranked fourth. Only $10 \%$ of people ranked earthquakes as their biggest concern. People understood that the damage of earthquakes is terrible (e.g., via social media), but they had never experienced a massive earthquake themselves (Guiyang is not in a seismic zone).

About $60 \%$ of participants thought that the flood events did not usually occur in their lives. Further, $38 \%$ of participants felt that the flood risk increased in the last 10 years because of climate change, building construction, and urbanization. A professional interviewee explained the possible reasons:

"Most residents living alongside Nanming River had an experience of flood events. Other residents who lived on higher altitudes recognized the flood issues from social media (e.g., newspapers and TV news) and new media channels (e.g., WeChat and Weibo). The perception of the flood is affected by people's living areas. Meanwhile, the knowledge, educational degree, and working experience influence the people awareness." (Interviewee I)

When asked about how they heard about the SCP, 77\% of respondents expressed that they had heard (or seen) the word (i.e., Sponge City) from TV news or newspapers. Most of them had never proactively gained information and knowledge about SCP. Regarding the relationships between the SCP and floods, $82 \%$ of residents thought the primary function of the SCP is to improve the urban landscape. They did not recognize that the SCP infrastructures, such as green-roofs, gardens, and wetland parks, have any contribution to flood prevention. The following was a typical response:

"I understand the flood prevention job is essential. The dams and floodwalls were certainly built to control the flood and protect us. Regarding the green garden and wetland park, I thought they provide us leisure places to enjoy. I don't understand how the gardens and parks can store the water to reduce the flood risk." (Interviewee $h$ )

About dealing with the occurrence of flood, $90 \%$ of respondents selected to call the emergency number (119 or 110). Aside from this, the residents showed very low preparedness. When asked if they understood the escape route, had a self-protection plan, or prepared emergency resources (e.g., water, food, and medicine), $76 \%$ of participants had no awareness. An official explained the results as follows:

"The Chinese Government has the relative centralized power to implement the rescue works. There were lots of successful stories in rescue tasks. Media channels broadly propagandized these heroes. Most of the citizens trust that the Government has the willingness and ability to protect them from natural hazards. On the other hand, many citizens have gradually lost self-protection sense due to the propagandas of the strong ability on governmental emergency management." (Interviewee G)

\section{Discussion-Looking Forward to UFM and SCP in Guiyang}

\subsection{Implementing Natural Flood Management (NFM) at the Catchment Scale}

As discussed in Sections 3 and 4, in Guiyang, significant flooding damage was caused by rare fluvial flood events. The grey infrastructure was able to improve the city's flood control ability. However, grey infrastructure has some drawbacks-first and foremost, it requires extensive financial investment. For example, the total investment of a reservoir with 10 million $\mathrm{m}^{3}$ water-storage capacity can be up to 1 billion RMB in Guiyang. 
In addition, dams and floodwalls can negatively impact both the urban landscape and associated ecosystems.

By comparison, SCP infrastructure is designed to absorb initial rainfall, and thus partly reduce urban surface flooding. However, the SCP program is predominantly applied only at the building, community, and district scale [53]. As a result, the SCP approach risks becoming a series of showcase studies unless it is better connected with the wider catchment management. Therefore, employing only grey or SCP measures is not suited to mountainous cities facing fluvial flood challenges such as Guiyang. Instead, the UFM policy should be extended to link individual district-scale flood controls to catchment-scale flood control.

CFMP could be a more suitable strategy for flood management in mountainous areas. It aims to integrate NFM in upstream tributaries, grey infrastructure on trunk reaches, and SCP in urban areas. NFM, grey infrastructure, and SCP, therefore, become subsets of CFMP [10]. We have explored the perceptions of the performance of grey infrastructure and SCP on flood management in Section 4. However, to extend flood management to CFMP, it is necessary to understand the NFM principle and practice it further.

The practices from the United Kingdom may enlighten NFM in Chinese cities. Several NFM projects have been implemented in the United Kingdom, such as Belford [54], Pickering [55], and Holnicote [56]. NFM is considered a sustainable alternative to traditional flood management on upstream tributaries [10]. The NFM of many U.K. pilot cases succeeded in reducing river flow on upstream tributaries to reduce flood risks on downstream trunk reaches [57]. The NFM methods include the following: (1) reducing surface water generated from hills on upstream tributaries (i.e., afforestation); (2) storing water to reduce river flows from upstream tributaries (i.e., wetland restoration); and (3) slowing water flow by reducing the connection between upstream tributaries and downstream flood areas (i.e., wood dam) [56].

The transformation from traditional flood management to integrated CFMP requires organizations, professionals, and residents to work more closely. Decision-makers need to improve cross-bureau mechanisms to reduce the conflicts within and between different governmental agencies. A pilot long-term CFMP that systematically includes NFM, grey infrastructure, and SCP needs to be implemented. The monitoring data from pilot projects can increase knowledge and experience, which be extended to other Chinese cities (rather than only embracing the notion of CFMP).

Generally, CFMP will benefit from greater integration of green with grey practices throughout the whole catchment. On trunk reaches, reservoirs and floodwalls can mainly reduce fluvial floods (beyond the 1-in-30 years standard). In the urban areas, existing and further improved drainage systems and SCP infrastructure can combine to reduce urban surface flow (below 1-in-30 years). NFM projects could be set up on upstream tributaries in rural areas, which would prolong water storage in the upper catchment and further reduce the flood peak flow to downstream urban reaches [56]. A more integrated CFMP could provide multiple potential ways of improving flood prevention ability, water quality, environmental amenity, and biodiversity.

\subsection{Improving People Awareness via Public Participation}

In the last 10 years, the Guiyang Municipal Government has started recognizing the importance of involving different actors and stakeholders (e.g., experts, engineers, developers, and citizens) in project planning [44]. It is a big step for administrative culture as this has not previously been the norm. In this study, we investigated some bureaus websites (Table 4). While we found that all bureaus have set public-participation pages, the websites provided the facility for the only online complaint rather than public participation of flood management (see http:/ / www.guiyang.gov.cn/hdjl/hdjlzxts/hdjlzxtszxts/wyxx_ zxzx / accessed on 22 November 2020).

During interviews with residents, it was found that most participants could not precisely describe the features and purpose of flood management. Most were also unfamiliar 
with public participation in the planning process. They also had less willingness to take part in flood management. For example, a typical answer was as follows:

"We hope the government can hear our voice. But we are not experts. Officials may not listen to us. In addition, we have no time on public affairs except for involving our benefits and interests." (Interview i)

Because the residents can directly feel flood damages, their suggestions and participation are essential to improve UFM. As a result of the above findings, we would suggest three steps that could be used to improve people awareness and public participation in the flood planning process. Firstly, more pro-people approaches are needed for public involvement. Instead of top-down (selected by authorities) delivery of information, inviting residents in small groups for knowledge exchange may show more respect to residents, and thus encourage greater involvement. Small group consultation meetings would also provide more time to discuss flood management and elicit suggestions for mitigation options. Frequent engagement is also important to improve the proactivity of participants. For example, the organizers can provide feedback on the reasons for selecting or not selecting participants' proposals.

Secondly, an effective way to increase attendance is by announcing public consultations immediately after significant flood events. The advantage is that people are more willing to participate in such meetings when there is a recent experience of the effects of flooding. In addition, consultation meetings could be held in flood-prone areas to discuss site-specific problems and mitigation measures. Public participation meetings could also be held outside of working hours to attract more working people. The use of non-technical language is also essential to ensure people understand the issues being discussed and keep their attention.

Thirdly, proactive information disclosure and monetary subsidies can be used to increase awareness and participation. Websites could be created to help people to identify flooding risk areas. Message boards could be set up in flood disaster areas to warn people and introduce rescue measures that could be used in each household. Furthermore, providing household subsidies for flood prevention resources may also increase public self-rescue awareness.

Meanwhile, the process of improving people awareness via public participation may face challenges. For instance, it needs more governmental budget, public donations, volunteers, enthusiastic officials, and resources. If not, public engagement could be limited as the authorities have little time, money, and employees.

\subsection{Developing Cooperative All Phases Emergency Management}

Under the existing organizational framework, the highest authority is the Guiyang Municipal Government. Other core bureaus related to flood management are shown in Figure 8 [5]. The Natural Resources Bureau takes charge of urban master planning. The Water Conservancy Bureau invests in and operates flood projects such as reservoirs and floodwalls. The Urban Construction Bureau oversees urban drainage systems, and the Emergency Management Bureau manages the rescue works [58]. An official noted the following:

"For the most part, the authorities can cooperate in flood management issues. However, there is a part of overlaps in bureaus' responsibilities." (Interviewee A)

"The overlapping power could challenge on the partnership on flood management. For example, the wetland parks were usually designed with less consideration of the urban drainage system in Guiyang. In addition, the Urban Construction Bureau put more focus on road and building infrastructures rather than considering the hydrological issues." (Interviewee B)

"It seems that the Emergency Management Bureau can coordinate all bureaus in emergency services and rescue jobs. Most time, the Emergency Management Bureau can order 
rescue teams. But we still have to apply for Municipal Government's coordination in real rescue works." (Interviewee H)

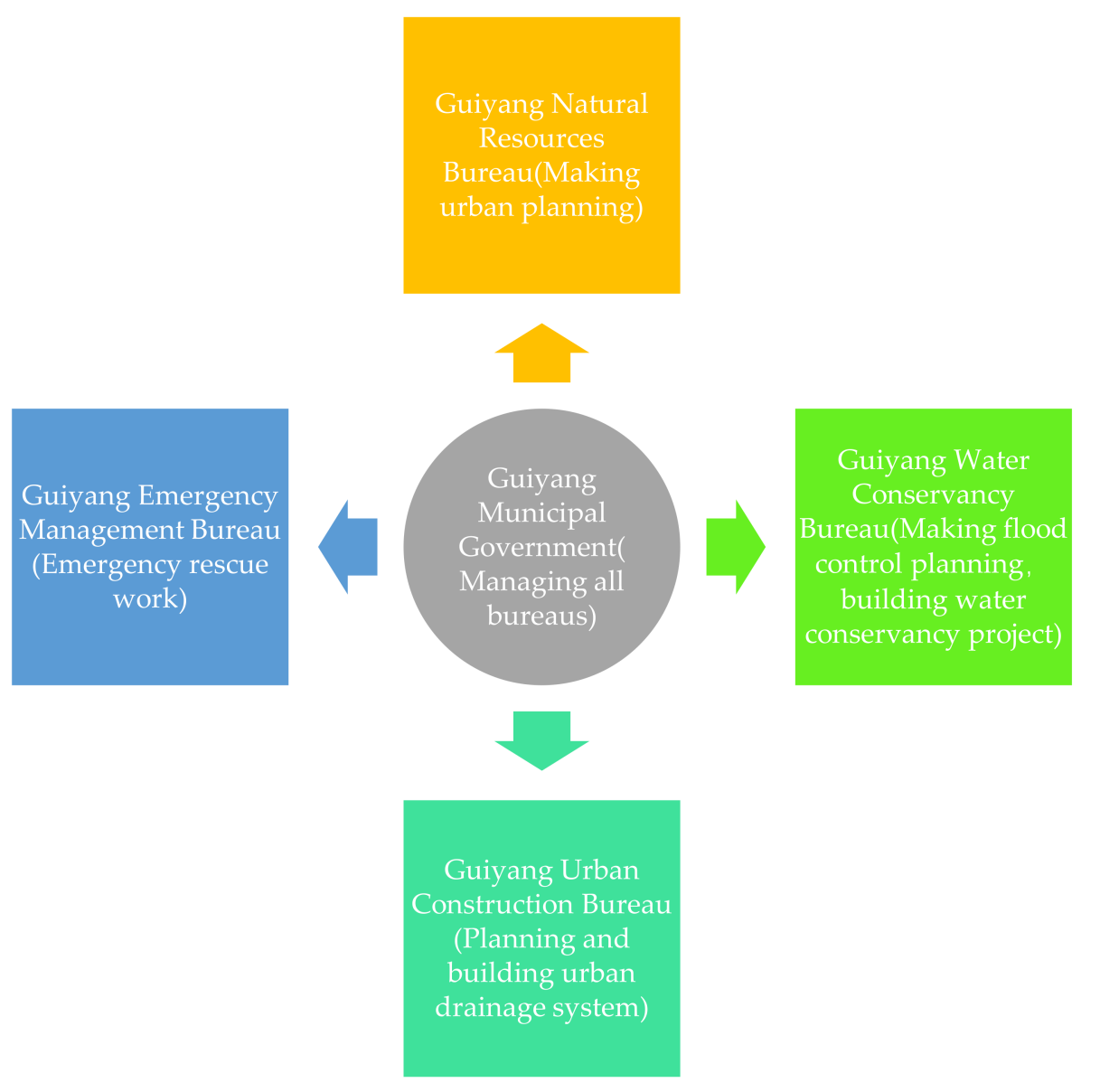

Figure 8. Bureaus and responsibilities. Drawn by authors.

To achieve a unified flood management strategy, the Natural Resources Bureau would need to include more specific regulations and laws to guide urban planning in managing floods [9]. For example, mandatory laws can be promulgated to reserve flood detention areas in cities' upper and middle reaches. The Water Conservancy Bureau also needs to consider greater use of green infrastructures, such as riverside wetland parks, to improve the landscape and water ecosystems, rather than only investing in grey infrastructure. The Urban Construction Bureau needs to establish guidelines to control the building density, and thus reserve more green spaces to store moderate rainwater. Ideally, the Emergency Management Bureau can work with the Municipal Government to implement emergency rescue to save people's lives and properties in hazards and be given the absolute authority to coordinate all bureaus in rescue tasks.

A so-called all phases emergency management approach links emergency and governmental activities before, during, and after emergency events. Policymakers easily conflate short-term preparedness, response, and recovery works, but neglect mitigation efforts in the long term [59]. In Guiyang, one reason for the enormous damages during the fluvial flood event on 2 July 1996 was that both government and society mainly focused on the post-disaster recovery rather than a prior-disaster warning and long-term preparedness. An all phases emergency management involves more long-term mitigation efforts [13]. Emergency management is not limited to short-term preparation, response, and recovery. On the contrary, emergency management authorities should play an active role in normal times by cooperating with other bureaus and mobilizing different participants, such as 
NGOs, social media, communities, the public, and insurance companies, to reduce potential disaster risks, thereby reducing the costs of disaster response and recovery.

\section{Conclusions}

Flooding is a natural phenomenon and impossible to avoid. Traditional flood management should integrate natural and social factors to help people live with floods. Guiyang has recently made significant achievements in UFM via innovative theory, technology, engineering, management policy, and technical standards. The city still has a long way to go to become a flood-proofed and more sustainable urban environment as envisaged by the SCP. Indeed, the future challenge for Sponge City implementation lies in delivering improvements in flood management to mountainous-valley cities such as Guiyang.

This challenge can be characterized by four main points identified within this study. First, the urban flood disaster is still severe in such cities owing to the challenges of climate change and rapid urbanization. Second, SCP infrastructure alone has a relatively low ability to cope with the catchment-scale fluvial flood. Third, water-related ecological services in urban environments are becoming increasingly important, making grey infrastructure increasingly unpopular. Fourth, the people awareness of flood preparedness is still at a low level.

To address the above challenges, policymakers will need to break the barriers between different bureaus, developers, professionals, and citizens by sharing more knowledge, information, and data. Urban planners and engineers will need to build a CFMP system further to integrate SCP infrastructure, grey infrastructure, and NFM. More innovational public participation can also be introduced to government, NGOs, media, and residents to improve people's awareness.

It is recommended that, for Guiyang in particular, a CFMP system should be established, including grey infrastructure, SCP, and NFM, so that priority can be given to catchment flood risk mitigation. Meanwhile, we suggest developing the SCP more holistically to reduce urban flood risk. In the context of the coordinated development of SW China, Guiyang will become a harmonious, ecological, and livable emerging city with Chinese characteristics if the above challenges can be met.

Author Contributions: Conceptualization, Y.Q. and F.K.S.C.; Resources, Data Collection, and Organization, Y.Q., S.L., L.L., C.Z. and X.L.; Writing-Original Draft Preparation, Y.Q. and F.K.S.C.; Writing-Review and Editing, J.G., M.F., E.O., M.H., M.S. and L.X.; Figures and Tables, L.L. and M.Z.; Supervision, Y.S., G.L. and D.R.T. All authors have direct contributions to the paper. All authors have read and agreed to the published version of the manuscript.

Funding: This research was funded by National Natural Science Foundation of China (NSFC) (Grant number: 41850410497); National Key R\&D Program of China (Grant number: 2019YFC1510400); National Natural Science Foundation of China (NSFC) Youth Project (Grant number: 51909126); University of Nottingham (UNUK) project (Grant number: E01200500006); Institute of Asia Pacific Studies Research Funded for the Environmental Security and Sustainability; Cultural and Creative Industries Research Priority Areas; Faculty of Science and Engineering (FoSE) Postgraduate Research Scholarship of University of Nottingham Ningbo China; and Guizhou Science and Technology Planning of Project (Grant number: 2019 2879).

Institutional Review Board Statement: Not applicable.

Informed Consent Statement: Not applicable.

Data Availability Statement: The authors collected the raw data from all participants. The results of the paper are supported by the original data. The original data are partly included in the paper. The authors will protect the participants' privacy. More inquiries can be directed to the corresponding authors.

Conflicts of Interest: All authors declare the research was in noncommercial or financial interest of any people and organizations. 


\section{References}

1. La Loggia, G.; Puleo, V.; Freni, G. Floodability: A New Paradigm for Designing Urban Drainage and Achieving Sustainable Urban Growth. Water Resour. Manag. 2020, 34, 3411-3424. [CrossRef]

2. Burian, S.J.; Edwards, F.G. Historical Perspectives of Urban Drainage. Glob. Solut. Urban Drain. 2002, 1-16. [CrossRef]

3. Francipane, A.; Pumo, D.; Sinagra, M.; La Loggia, G.; Noto, L.V. A paradigm of extreme rainfall pluvial floods in complex urban areas: The flood event of 15 July 2020 in Palermo (Italy). Nat. Hazards Earth Syst. Sci. 2021, 21, 2563-2580. [CrossRef]

4. Rosenzweig, B.; Ruddell, B.L.; McPhillips, L.; Hobbins, R.; McPhearson, T.; Cheng, Z.; Chang, H.; Kim, Y. Developing knowledge systems for urban resilience to cloudburst rain events. Environ. Sci. Policy 2019, 99, 150-159. [CrossRef]

5. Guiyang Municipal Government. Guiyang Emergency Plan for Flood Control and Drought Relief; Guiyang Municipal Government: Guiyang, China, 2020.

6. Wu, Y.; Liu, J.; Xie, H.; Yu, G.; Zhou, H.; Yan, Y. Towards government mechanisms of sponge city construction in China: Insights from developed countries. Water Policy 2020, 22, 574-590.

7. Griffiths, J.; Chan, F.K.S.; Shao, M.; Zhu, F.; Higgitt, D.L. Interpretation and application of Sponge City guidelines in China. Philos. Trans. A Math Phys. Eng. Sci. 2020, 378, 20190222. [CrossRef]

8. Li, H.; Ding, L.; Ren, M.; Li, C.; Wang, H. Sponge City Construction in China: A Survey of the Challenges and Opportunities. Water 2017, 9, 594. [CrossRef]

9. Wang, H.; Mei, C.; Liu, J.; Shao, W. A new strategy for integrated urban water management in China: Sponge city. Sci. China Technol. Sci. 2018, 61, 317-329. [CrossRef]

10. Wingfield, T.; Macdonald, N.; Peters, K.; Spees, J.; Potter, K. Natural Flood Management: Beyond the evidence debate. Area 2019, 51, 743-751. [CrossRef]

11. Qi, Y.; Chan, F.K.S.; Thorne, C.; O’Donnell, E.; Quagliolo, C.; Comino, E.; Pezzoli, A.; Li, L.; Griffiths, J.; Sang, Y.; et al. Addressing Challenges of Urban Water Management in Chinese Sponge Cities via Nature-Based Solutions. Water 2020, 12, 2788. [CrossRef]

12. Ministry of Water Resources. 2018 Statistic Bulletin China Water Activities; Ministry of Water Resources: Beijing, China, 2018.

13. Chan, F.K.S.; Yang, L.E.; Scheffran, J.; Mitchell, G.; Adekola, O.; Griffiths, J.; Chen, Y.; Li, G.; Lu, X.; Qi, Y.; et al. Urban flood risks and emerging challenges in a Chinese delta: The case of the Pearl River Delta. Environ. Sci. Policy 2021, 122, 101-115. [CrossRef]

14. Liu, J.; Zang, C.; Tian, S.; Liu, J.; Yang, H.; Jia, S.; You, L.; Liu, B.; Zhang, M. Water conservancy projects in China: Achievements, challenges and way forward. Glob. Environ. Chang. 2013, 23, 633-643. [CrossRef]

15. Qi, Y.; Chan, F.K.S.; O’Donnell, E.C.; Feng, M.; Sang, Y.; Thorne, C.R.; Griffiths, J.; Liu, L.; Liu, S.; Zhang, C.; et al. Exploring the Development of the Sponge City Program (SCP): The Case of Gui'an New District, Southwest China. Front. Water 2021, 3. [CrossRef]

16. Ministry of Housing and Urban-Rural Development. The Construction Guideline of Sponge City in China-Low Impact Development of Storm Water System (Trail); Ministry of Housing and Urban-Rural Development: Beijing, China, 2014.

17. Standing Committee of the National People's Congress. The Water Law; Standing Committee of the National People's Congress: Beijing, China, 2016.

18. The National Council. The Announcement of Strengthening Urban Flood Control Works; The National Council: Beijing, China, 1989.

19. Ministry of Water Resources. The Outline of Urban Flood Control Planning; Ministry of Water Resources: Beijing, China, 1990.

20. The National People's Congress. The National Flood Control Law (Revised in 2007); The National People's Congress: Beijing, China, 2007.

21. The General Office of Flood Defense. The Notice of Strengthening Urban Flood Control Planning; The General Office of Flood Defense: Beijing, China, 2011.

22. The National People's Congress. The National Law of Urban and Rural Planning; The National People's Congress: Beijing, China, 2019.

23. The National People's Congress. The National Land Management Law; The National People's Congress: Beijing, China, 2019.

24. Guiyang Municipal Government. The Master Plan of Guiyang City; Guiyang Municipal Government: Guiyang, China, 2015.

25. Guizhou Local Chronicles Committee. The Economy and Population Development of Guiyang. Available online: http://www. gzdafzxx.cn/ (accessed on 2 May 2020).

26. Statistics Bureau of Guiyang. Statistical Bulletin. Available online: http://tjj.guiyang.gov.cn/tjsj/tjsjtigb/ (accessed on 1 May 2020).

27. Guiyang Municipal Government. The Sponge City Planning of Guiyang Central City (2019-2030); Guiyang Municipal Government: Guiyang, China, 2019.

28. Thorne, C.R.; O'Donnell, E.C.; Ozawa, C.P. Overcoming uncertainty and barriers to adoption of Blue-Green Infrastructure for urban flood risk management. J. Flood Risk Manag. 2015, 10. [CrossRef]

29. Standing Committee of the Guizhou People's Congress. Guizhou Regulation for Flood Control; FAO: Guiyang, China, 2003; revised in 2017.

30. Standing Committee of the Guizhou People's Congress. Guizhou Regulation for River Administration; Standing Committee of the Guizhou People's Congress: Guiyang, China, revised in 2019.

31. Standing Committee of the Guiyang People's Congress. The Regulation of Guiyang Urban Planning and Management; Standing Committee of the Guiyang People's Congress: Guiyang, China, revised in 2006.

32. Standing Committee of the Guiyang People's Congress. Guiyang Regulation for River Administration; Standing Committee of the Guiyang People's Congress: Guiyang, China, revised in 2004. 
33. Catherine, S.R.; Kirsti, N.; Marie, L.R. Conducting the Reference Interview, 3rd ed.; Neal-Schuman: New York, NY, USA, 2019.

34. Bolderston, A. Conducting a Research Interview. J. Med. Imaging Radiat. Sci. 2012, 43, 66-76. [CrossRef]

35. Qu, S.Q.; Dumay, J. The qualitative research interview. Qual. Res. Account. Manag. 2011, 8, 238-264. [CrossRef]

36. Galletta, A.; Cross., W.E. Mastering the Semi-Structured Interview and Beyond: From Research Design to Analysis and Publication; NYU Press: New York, NY, USA, 2013.

37. Edwards, R.; Holland, J. What Is Qualitative Interviewing? Bloomsbury Academic: London, UK, 2013.

38. Guiyang Municipal Government. Guiyang Water Supply and Discharge Special Plan for 13th Five-Year; Guiyang Municipal Government: Guiyang, China, 2015.

39. Guizhou Survey \& Design Research Institute for Water Resources and Hydropower. The Comprehensive Water Resources Planning for Guiyang; National Research Center for Resettlement: Guiyang, China, 2016.

40. Guizhou Survey \& Design Research Institute for Water Resources and Hydropower. The Flood Control Planning for Guiyang; Guizhou Survey \& Design Research Institute for Water Resources and Hydropower: Guiyang, China, 2016.

41. Guizhou Survey \& Design Research Institute for Water Resources and Hydropower. Flood Control Evaluation of Nanming River Regulation Project; Guizhou Survey \& Design Research Institute for Water Resources and Hydropower: Guiyang, China, 2016.

42. Guizhou Survey \& Design Research Institute for Water Resources and Hydropower. The Construction Planning of Flood Control Infrastructures for Guiyang; Guizhou Survey \& Design Research Institute for Water Resources and Hydropower: Guiyang, China, 2018.

43. Guiyang Municipal Government. Guiyang Emergency Plan for Flood Control and Drought Relief; Guiyang Municipal Government: Guiyang, China, 2018.

44. Hydrology Bureau of Guizhou Province. Flood Report of Guizhou Province; Hydrology Bureau of Guizhou Province: Guiyang, China, 2015.

45. Guiyang Municipal Government. The Sponge City Implementational Plan for Guiyang; Guiyang Municipal Government: Guiyang, China, 2016.

46. Guiyang Municipal Government. The Sponge City Construction Planning of Guiyang Central City (2016-2030); Guiyang Municipal Government: Guiyang, China, 2016.

47. Guiyang Municipal Government. Available online: http://www.guiyang.gov.cn/ (accessed on 22 November 2020).

48. Guiyang Water Conservancy Bureau. Available online: http://swglj.guiyang.gov.cn/ (accessed on 21 November 2020).

49. Guiyang Natural Resources Bureau. Available online: http:/ /zyghj.guiyang.gov.cn/ (accessed on 20 November 2020).

50. Guiyang Emergency Management Bureau. Available online: http:/ /yjj.guiyang.gov.cn/ (accessed on 20 November 2020).

51. Guiyang Urban Construction Bureau. Available online: http:// zhujianju.guiyang.gov.cn/ (accessed on 19 November 2020).

52. Chan, F.K.S.; Chuah, C.J.; Ziegler, A.D.; Dabrowski, M.; Varis, O. Towards resilient flood risk management for Asian coastal cities: Lessons learned from Hong Kong and Singapore. J. Clean. Prod. 2018, 187, 576-589. [CrossRef]

53. Xiang, C.; Liu, J.; Shao, W.; Mei, C.; Zhou, J. Sponge city construction in China: Policy and implementation experiences. Water Policy 2019, 21, 19-37. [CrossRef]

54. Short, C.; Clarke, L.; Carnelli, F.; Uttley, C.; Smith, B. Capturing the multiple benefits associated with nature-based solutions: Lessons from a natural flood management project in the Cotswolds, UK. Land Degrad. Dev. 2019, 30, 241-252. [CrossRef]

55. Iacob, O.; Brown, I.; Rowan, J. Natural flood management, land use and climate change trade-offs: The case of Tarland catchment, Scotland. Hydrol. Sci. J. 2017, 62, 1931-1948. [CrossRef]

56. Dadson, S.J.; Hall, J.W.; Murgatroyd, A.; Acreman, M.; Bates, P.; Beven, K.; Heathwaite, L.; Holden, J.; Holman, I.P.; Lane, S.N.; et al. A restatement of the natural science evidence concerning catchment-based 'natural' flood management in the UK. Proc. Math. Phys. Eng. Sci. 2017, 473, 20160706. [CrossRef] [PubMed]

57. Lane, S.N. Natural flood management. Wiley Interdiscip. Rev. Water 2017, 4. [CrossRef]

58. Li, N.; Qin, C.; Du, P. Multicriteria Decision Analysis Applied to Sponge City Construction in China: A Case Study. Integr. Environ. Assess. Manag. 2019, 15, 703-713. [CrossRef] [PubMed]

59. Lu, X.; Han, Z. Emergency management in China: Towards a comprehensive model? J. Risk Res. 2018, 22, 1425-1442. [CrossRef] 